\title{
New State Economic Policy - Cluster Policy Cluster Policy as the Factor of Innovative Development of Europe
}

\author{
Gafurov I.R. \\ Platonova 0.U. \\ Pratchenko O.V.
}

Kazan Federal University, Kazan, 420008, Russia

\section{Doi:10.5901/mjss.2014.v5n12p107}

\begin{abstract}
Scenario of long-term economic development presupposes increase of its competitiveness in traditional and new knowledgeintensive sectors, breakthrough in quality improvement of human capital and dynamics of labor productivity, in priority development of high-quality production and transformation of innovative factors into the main source of growth.

Solving of these problems will require to create the system of detailed coordination of state, business, science and education on the basis of use of efficient instruments of innovative development, and now the cluster approach plays rather important role among them. Experience of clusterization of the western economy proves success of close territorial cooperation of different agents of industrial chain. Formation of new economy is connected with blurring of lines between countries and formation of network society based on economic clusters.
\end{abstract}

Keywords: cluster, industrial cluster, regional cluster, clusterization, innovation, innovative development, cluster-network development of economy.

\section{Introduction}

Innovative activity unites industrial groups, institutions of higher education and scientific institutions, financial sector. Life showed that the institution of policy of innovations is impossible without stable ties between these social institutions.

The fact that at present the countries of European community show stable innovative development is the evidence of this statement. And development is in such spheres as biotechnologies and information technologies where expenses for comprehensive analysis are especially high. Nevertheless, cost loading can be reduced at the expense of business combination and consolidation of companies and scientific communities which work with similar projects and in allied sciences. In this aspect we come across with globalization, creation of network society by search of corresponding source of finance, human resources and companies that wish to implement innovative products.

Experience of countries and territories which are the world epicenters of generating of innovations shows that transition of economic systems to the new growth pattern starts from creation of special cluster-network environment. In order to speed up such transition, in different types of economies a task to create clusters is in the center of their economic policies. Exactly cluster approach leads to encouragement of innovations and innovative growth in whole with the help of synergetic effect of cooperation.

\section{Theory}

Recently the concept of cluster (industrial cluster, regional cluster) has become very popular, so even high officials, experts, academicians apply to it more and more [1]. However, despite the fact that clusterization is the subject of scrutiny of scientists and experts, there is no one common terminological name for designation of this economic phenomenon. 
Table 1: Main terminological names of the category "cluster"

\begin{tabular}{|c|c|}
\hline Author & Definition \\
\hline $\begin{array}{l}\text { Anne-Wil Harzing } \\
\text { \& Axèle Giroud }\end{array}$ & $\begin{array}{l}\text { Industrial cluster is the number of economic sectors connected as the ties "customer-supplier" or "supplier- } \\
\text { customer", or by general technologies, general channels of purchase and distribution, or general organizations [2]. }\end{array}$ \\
\hline Schmitz & Cluster is the group of enterprises which belong to one economic sector and which function close to each other [3]. \\
\hline $\begin{array}{c}\text { Swann and } \\
\text { Prevezer }\end{array}$ & $\begin{array}{l}\text { Clusters are groups of companies within one economic sector which are situated in one and the same geographical } \\
\text { area [4]. }\end{array}$ \\
\hline Porter & $\begin{array}{l}\text { Cluster is geographically close group of related companies and cooperating institutions in special filed which are } \\
\text { connected by similarities and complementarity [5]. }\end{array}$ \\
\hline Elsner & $\begin{array}{l}\text { Cluster is the group of companies which are functionally connected, vertically and horizontally. Functional approach } \\
\text { emphasizes quality of existing interconnections between companies and institutions which support cluster, and such } \\
\text { interconnections are determined by market [6]. }\end{array}$ \\
\hline $\begin{array}{l}\text { Steiner and } \\
\text { Hartmann }\end{array}$ & $\begin{array}{l}\text { Cluster is a number of complementary companies (in industrial or service sectors) of public, private and quasi public } \\
\text { research institutions and development institutions which are connected by labor market and/or ties of costs - of } \\
\text { production output and/or technological ties [7]. }\end{array}$ \\
\hline $\begin{array}{l}\text { Bergman and } \\
\text { Feser }\end{array}$ & $\begin{array}{l}\text { Regional clusters are industrial clusters which are concentrated geographically, usually within the region which } \\
\text { forms metropolitan area, labor market and other functional economic units [8]. }\end{array}$ \\
\hline Andersson et al. & $\begin{array}{c}\text { In general terms clusterization is interpreted as process of colocation of companies and other parties within } \\
\text { concentrated geographical area, cooperation around definite functional niche and establishment of close } \\
\text { interconnections and labor alliances in order to increase their collective competitiveness [9]. }\end{array}$ \\
\hline
\end{tabular}

Summing up all the above-mentioned definitions, it is necessary to say that essence of cluster reflects three compulsory components (Fig. 1.).
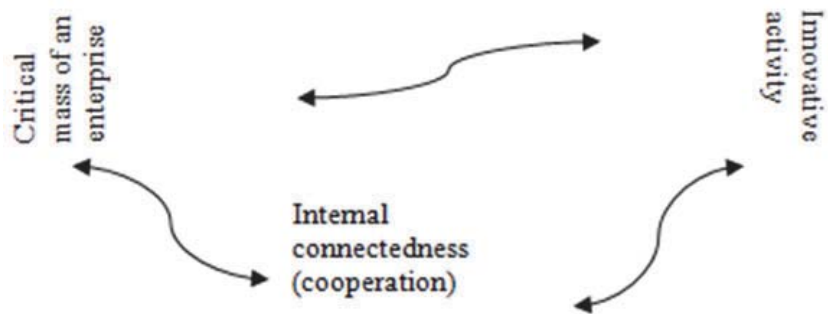

Fig. 1.Compulsory combination of three special features of the cluster

Cluster is concentration of companies in general field of activity.

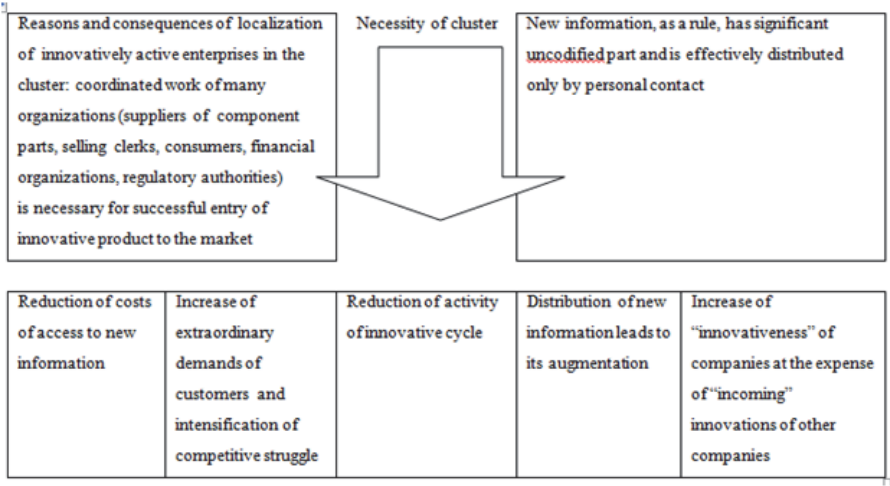

Fig. 2. Reasons and consequences of localization of innovatively active enterprises in the cluster 
Economic reason of formation and existence of cluster is in the fact that cluster gives some advantages to its participants; these advantages are called external economy (externalities), by analogy with internal economy because of scale of production. Assessment of internal and external economy on micro level - on the level of a company - can be executed with the help of the following formulas:

1. external economy for the company is hidden in total factor productivity:

$Y=A * K a$ it ${ }^{*} L^{\beta}$ it

where $Y$ is production or added value of company $i$ in period of time $t$;

Kit - capital used by company i in period of time t;

Lit - labor used by company $i$ in period of time t;

a) $a$ - production elasticity (of added value) by capital;

b) $\beta$ - production elasticity (of added value) by labor;

A - total factor productivity.

2. total factor productivity depends on factors inside the company (internal economy) and external factors (external economy):

\section{$A=$ Lut it * Ext ${ }^{s z_{i t}}$}

where Lut it - index which reflects internal economy of company i in period of time t;

Ext $s z$ it - index which reflects external economy in industry sector $s$ on the territory $z$, which influences the company $\mathrm{i}$ in period of time $\mathrm{t}$;

\section{Results}

\subsection{Analysis of clusterization of international economies}

Innovative activity unites industrial groups, institutions of higher education and scientific institutions, financial sphere. Life showed that policy of innovations is impossible without stable ties between these social institutions of society. World practice shows that during the last two decades process of formation of clusters was going rather actively. In whole, according to the experts' research, now about $50 \%$ of economies of the leading countries of the world are clusterizationstruck

In the countries of European community there are more than 2000 clusters, in which $38 \%$ of its labor force is employed. These indexes emphasize aspects of innovations, speed of distribution of new information and technologies. The fact that at present moment the countries of European community demonstrate stable innovative development is the evidence of it. And development is in such fields as biotechnology and information technologies, where expenses for comprehensive analysis are especially high. Nevertheless, cost loading can be reduced at the expense of business combination and consolidation of companies and scientific communities which work with similar projects and in allied sciences. In this aspect we come across with globalization, creation of network society by search of corresponding source of finance, human resources and companies that wish to implement innovative products.

Experience of countries and territories which are the world epicenters of generating of innovations shows that transition of economic systems to the new growth pattern starts from creation of special cluster-network environment. In order to speed up such transition, in different types of economies a task to create clusters is in the center of their economic policies. Exactly cluster approach leads to encouragement of innovations and innovative growth in whole with the help of synergetic effect of cooperation.

\subsection{National characteristics of clusterization of European economy}

Modern state policy in the sphere of promotion of clusters is determined by many national peculiarities.

For example, in France cluster policy is implemented in the frames of the program of creation of poles of competitiveness - interrelated networks of different companies (large, medium and small enterprises, scientific research centers, institutions and laboratories) on the regional, national and European levels. The following clusters are the most significant ones: "Secure Communication Solutions" (information technologies, in "Sofia-Antipolis"), "Systematic" (optics, electronics and software, in Paris region), "Aerospace valley" in Toulouse, "Minilogic" (Nanotechnologies and embedded systems) in Grenoble. And the last one is the most vivid example of the cluster appeared in natural way but with assistance of the public sector. And the technological cluster "Sofia-Antipolis" was formed in the region where there is no industry, university traditions, no social network.

In Great Britain, Spain, Hungary and Czech Republic state policy is aimed not so much at creation of new clusters, 
as at mobilization of already existing regional resources in the frames of most of the already existing clusters.

The cluster policy of Germany which has been implemented on the federal level since the mid 1990s can be of some interest for Russia. German experts connect its appearance with new challenges after reunification of Germany.

In Germany all programs of cluster promotion are divided into two categories. Programs of the first one are directed at encouragement of the most promising researches and creation of new technological companies. They are based on network cooperation of research companies with business. And, as a rule, the headmost economically developed regions (Munich/Upper Bavaria) obtain support. Network programs of the second category (InnoRegio, "Innovative Regional growth centers") are aimed at change of structure of regions, in particular, at achievement of innovative potential in new federal lands. The programs "Network management Vostok" and "InnoWatt" have the same aim. Funds provided in the frames of special events for promotion of networks, are given for the period from 6 months to 5 years, and during this time (or after accomplishment of the program) assessment of its efficiency is certainly made [10].

German approach for introducing of innovative technologies proved its efficiency. After implementation of the programs of innovative development new clusters appear (for example, 14 innovative clusters appeared in Germany during implementation of "Pact for Research and Innovation").

Apart from national programs, a lot of programs (with administration of federal lands as their initiator) go in Germany. In Germany great attention is paid to detection and distribution of successful practices. The program "Business competition of leading clusters" (2007-2011), in the frames of which support to 15 clusters was given to, can be the example of it.

In total they received $600 \mathrm{mln}$. euro from the state and the same sum - from business [11].

Besides, at present the project "go-cluster", the main task of which is to provide help to management structures (management) of clusters in order to increase their competence and to teach participants of innovative networks on the most successful examples of work, is implemented under the authority of Federal Ministry of economy and Technologies. The project unites 68 innovative clusters, in which 5500 small business and moderate size companies, 1300 big companies and 1500 research institutions work and cooperate [12].

Innovative clusters are in the center of attention of EU leadership. A number of All-European programs and initiatives, in particular, PRO INNO Europe, Europe INNOVA, "Regions of knowledge", "Enterprise Europe Network" $(\mathrm{EEN})$, European Cluster Excellence Initiative and others, indicate this. Active measures to integrate European companies into strategic unions are carried out. Cross-border cooperation is the priority.

\section{Conclusion}

The results of European policy in the sphere of innovations are the following: now there are 2000 clusters in 32 countries of Europe. And European countries think that computer technologies, nanotechnologies and biotechnologies, their symbiosis should play key role in development of innovative products.

Ranging of countries by the innovation index (GII - Global Innovation Index) within European community is relatively stable; Sweden is the leader of this rating, Germany, Denmark and Finland are the leaders of rating among the countries with high indexes of innovations. Estonia, Lithuania and Latvia have significantly improved their position in this rating since the beginning of 2013. However, fall of investment in innovation sphere during the last years (crisis years 2008-2013) negatively influenced innovative activity.

Thus, the leaders of innovations in the European Union are divided into four groups (according to GII): 1.Leaders of innovations: Sweden, Germany, Denmark and Finland. 2. Countries that follow leaders: Netherlands, Luxembourg, Belgium, Great Britain, Austria, Ireland, France, Slovenia, Cyprus and Estonia. 3. Moderate innovators: Italy, Spain, Portugal, Czech Republic, Greece, Slovakia, Hungary, Malta and Lithuania. 4. Modest innovators: Poland, Latvia, Romania and Bulgaria.

The most innovatively developed countries of EC (the first group) spend significant funds to hold national researches, to provide conditions for development of business partnership in the sphere of innovation between industry and science.

\section{References}

Françoise, Le Bail.The concept of clusters and cluster policies and their role for competitiveness and innovation: main statistical results and lessons learned // Europe Innova/Pro Europe paper. - 2008. -№ 9. - 78 pp.

Anne-Wil Harzing , Axèle Giroud. The competitive advantage of nations: An application to academia University of Melbourne Department of Management and Marketing Parkville Campus. -Australia: Victoria 3010, 2011 - 94 pp. 
Schmitz, Hubert. On the Clustering of Small Firms. - IDS Bulletin (Special Issue), 2012, 23(3) - pp. 64-69.

Kirshin I.A., Datsyk A.A., Titov A.V. Forecasting the Dynamics of an Innovative Cycle. - World Applied Sciences Journal (Economics, Management and Finance). - 2013. - №27. - P. 197 - 201.

Glebova I.S., Sadyrtdinov R. and Rodnyansky D. Impact Analysis of Investment Attractiveness of the Republic of Tatarstan on Fixed Investments of its Leading Companies // World Applied Sciences Journal 26 (7): 911-916, 2013.

Swann G. M. P., Prevezer M. and Stout, D., eds., The Dynamics of Industrial Clustering: International Comparisons in Computing and Biotechnology.- Oxford: Oxford University Press, 2013. -135 pp.

Melnik A.N. The Organization of Russian Power Market in Modern Conditions / A.N. Melnik, O.N. Mustafina // Middle-East Journal of Scientific Research. - 2013. - v. 13 - pp. 91-94.

Gainova R.A., Shaidullin R.N., Safiullin L.N. and Maratkanova E.M. Infrastructural Component in Maintenance of Competitiveness of Region// World Applied Sciences Journal, 27(13), 2013, pp. 97-101.

Ajupov A.A. Risk-Engineering, As an Element of Financial Engineering in the Market of Innovative Financial Products, 27(13), 2013, pp. 5-9.

Porter, M.E. On Competition. - Cambridge, Mass.: Harvard Business School Press, 2011. - 98 pp.

Elsner, W. An industrial policy agenda 2000 and beyond: Experience, Theory and Policy. Bremen Contributions to Institutional and Social-Economics (Eds.) - Grenzdorffer, K. - No 34. - 2013 . - 32pp.

Askhatova L.I., Fatkhiev A.M., Safiullin L.N. and Safiullina A.M. Competitive Strategies Formation in High Technology Enterprise // World Applied Sciences Journal, 27(13), 2013, pp. 20-23.

Safiullin, M.R., Safiullin, A.R., Ermolaeva, P. O., Noskova, E.P. (2013). Interdisciplinary Approach to the Analysis of the Competiteveness Types of the Economic Activities Based on the Example of the Oil and Gas Industry (Republic of Tatarstan Case). Middle-East Journal of Scientific Research 18, 1, $42-49$.

Bergman, E.M. and Feser, E.J. Industrial and Regional Clusters: Concepts and Comparative Applications /E. M. Bergman, E. J. Feser. Regional Research Institute, WVU.- 2009 - 78 pp.

Jappe Heinze A., Baier E., Kroll H. Clusterpolitik: Kriterien fur die Evaluati-on von regionalen Clusterinitiativen / Arlette Jappe-Heinze, Elisabeth Baier, Henning Kroll: Fraunhofer Institut System- und Innovationsforschung. Arbeitspapiere Unternehmen und Region. 2011. № 3. - pp. 54 - 73. 
